Inga B. Kuźma*

\title{
WPROWADZENIE DO ANTROPOLOGICZNYCH BADAŃ WŚRÓD BEZDOMNYCH KOBIET. CHARAKTERYSTYKA RELACJI DIALOGICZNEJ
}

\section{BADANIA TERENOWE ${ }^{1}$}

W niektórych podręcznikach do prowadzenia badań jakościowych artykułuje się wprost, że od chwili zajęcia się życiem innych - co może czasem przyjąć formę uczestnictwa w nim - naukowiec „staje się podstawowym instrumentem lub medium, za pomocą którego badanie jest przeprowadzane" (L o fl an d i in. 2009: 24). Taką postawę można określić - za przywołanymi autorami - jako naturalistyczną, zaś epistemologia, z której owa postawa wyrasta, „polega na przekonaniu, że tylko poprzez bezpośrednią obserwację i/lub partycypację badacza można zbliżyć się do zrozumienia badanych osób oraz natury ich społecznych światów i życia" (L o fla nd i in. 2009).

Cytowani przeze mnie autorzy otwarcie mówią także, że „badania terenowe bardziej niż jakikolwiek inny rodzaj badań społecznych wykorzystują osobiste związki badacza z otaczającym(i) go światem/światami”" (L o flan d i in. 2009: 32). Podejście naturalistyczne umożliwia badaczowi podjęcie tematów bliskich jego osobistym doświadczeniom oraz zainteresowaniom i wówczas stają się one punktem wyjścia dla działań terenowych. Pewne aspekty i wątki własnej biografii mogą także czasami ułatwić badaczowi dostęp do badanego środowiska. Lofland i Snow powołują się w tym miejscu na Jeffreya Riemera, który ten rodzaj badań

* Dr, adiunkt, etnografka, specjalność antropologia kulturowa, Zakład Antropologii Kulturowej, Instytut Etnologii i Antropologii Kulturowej, Uniwersytet Łódzki, ul. Pomorska 149/153, 90-236 Łódź,inga.kuzma@uni.lodz.pl.

1 Na wzór Stanisława W ę g 1 a r z a (2010: 12-13) chcę podkreślić, że podążanie za pewnymi cudzymi rozpoznaniami wynika z przyjęcia ich przeze mnie „za swoje” oraz z identyfikowania się z nimi - niektórzy szli podobną drogą badawczą, którą ja obecnie podążam. Np. własną postawę badawczą traktuję jako w dużej mierze naturalistyczną, której zwolennikami są cytowani tu John i Lyn H. L o fla n d ow i e, S n ow i A n d e r s o n (2009). Nie istnieje zatem powód, aby podzielanych z kimś diagnoz i intuicji związanych z terenem nie nazywać słowami definiującymi już dane doświadczenie. Jak to ujął Węglarz: „nasze wypowiedzi są w gruncie rzeczy cytatami, które wyrażone w jawnej postaci uczciwie oddają nasze długi myślowe” (W ę g 1 a r z 2010: 13). 
nazwał „wykorzystującymi okoliczności” (L o fland i in. 2009: 32). Pretekstu dostarczają więc np. problemy, które nurtują naukowców osobiście, choć w nauce dążącej do zachowania neutralności duża część osób wzdraga się przed ujawnieniem tego typu podłoża uprawianych przez siebie badań. Wydaje się bowiem, że może być źle przyjęte ,obnażanie się" przez badaczy: nie powinni oni „odsłaniać swojej duszy, ale raczej stosowane procedury" (L o fl and i in. 2009: 33).

Powstało wiele prac, w których poruszono temat bezdomności, zwłaszcza autorstwa socjologów i specjalistów od resocjalizacji, pracy socjalnej oraz pracowników służb socjalnych. Nie są to jednak teksty, które cechuje szczególne uwrażliwienie na kwestie gender (choć traktuje się jako oczywiste, że bezdomność kobiet jest inna niż mężczyzn, o czym zapewniają mnie np. pracownicy socjalni), ani nie zwracają one specjalnej uwagi na kwestię organizacji życia, jaka jest udziałem bezdomnych. Polega ona na swoistych subwersjach, technikach adaptacyjnych itp., stosowanych przez nich w placówkach zajmujących się pomocą socjalną i na ulicy. Skupienie uwagi naukowców i praktyków głównie na przyczynach bezdomności i kwestiach, jak zracjonalizować strategie pomocowe, nie oznacza, że ich diagnozy wyczerpują to zagadnienie i wystarczają do zrozumienia i opisania świata, w jakim żyją bezdomni. Szczególnie interesujące jest dla mnie, jak osoby zgłaszające się bądź odsyłane do instytucji świadczących pomoc, są poddawane rozmaitym technikom i strategiom dyscyplinującym, które przekształcają ich w „bezdomnych” i „potrzebujących”, a także jak owe procedury działają, by zmienić jednostkę, która opuszcza krąg pomocy - zaczynając nowe życie na własny rachunek. Czasami ktoś wraca do punktu wyjścia, czyli wychodzi poza system pomocowy, okresowo korzystając z niego. Poza tym zależni od pomocy posługują się nią w swoisty sposób. Otrzymywanie pomocy, choć pozwala przetrwać, nie poprawia ogólnej kondycji - wytwarza stan zawieszenia i wejście w obieg specyficznych transakcji. Oznacza zamienienie się w „klienta”. Odwołanie się do nomenklatury z zakresu usług i rynku zmienia wyobrażenie zarówno o celu świadczenia pomocy, jak i o statusie osoby nią obdarzanej oraz - co ważniejsze - kwalifikowanej do określonego rodzaju pomocy. Kwalifikacja ta rzadko obecnie przebiega bezwarunkowo. Idea miłosierdzia, choć historycznie i kulturowo (w tym emocjonalnie) kształtuje naszą wyobraźnię społeczną, jest raczej pewnym widmem, które spotkać można na obrzeżach współczesnego systemu pomocy. Używam określeń „system pomocy”, „obieg pomocy”, „instytucje pomocowe”, „klienci”, a nie czystego terminu „pomoc” lub „dzielący się/obdarowujący pomocą”, ,pomagający”, lub „,beneficjenci pomocy”, ponieważ te dwa szeregi słów przekazują inne sensy kulturowych działań zorganizowanych wokół idei dawania/brania wsparcia.

Mogę się zaliczyć do tego grona badaczy, którzy w specyficzny sposób czytają przestrzeń miejską i w swoje codzienne doświadczenie wpisują obecność miejskich „wyrzutków” (podobnie jak np. Claudia M. G i ro la (1996)). Przyciągają uwagę, ponieważ są skandalem (mimo wiedzy, iż analogiczne grupy występowały 
niemal w każdych czasach i być może w każdym miejscu). Wyrażenie „skandal” nie powinno być interpretowane w tym przypadku, jako wstęp do moralitetu społecznego, który chciałabym tu przedstawić. Zajmowanie się pisaniem programów ideologicznych, moralitetów i manifestów nie leży w moich kompetencjach badaczki, jaką się staram być mimo specyficznych zainteresowań. Być może właśnie ze względu na poważniejsze zajęcie się zagadnieniem bezdomności zachowuję coraz większy dystans wobec nauki, która chciałaby programowo uwrażliwiać lub wstrząsać. Według mnie nie służy to ani nauce ani sprawie objętej tak swoistym działaniem.

Oprócz codziennych doświadczeń, głównym powodem zajęcia się tą tematyką było inne moje zajęcie zawodowe pozauniwersyteckie, związane z działalnością wolontariacką. Zdecydowałam w pewnym momencie, by połączyć te dwie sfery: antropologię i działanie poza antropologią. Interesowało mnie coś więcej niż stosowanie antropologii dla niej samej lub poszukiwanie dogodnego środka (jak np. wolontariat) dla zajmowania się antropologią „zaangażowaną”.

Istotnym czynnikiem wzmacniającym mój wybór terenu była też wiedza nabywana sukcesywnie razem $\mathrm{z}$ coraz głębszym wchodzeniem $\mathrm{w}$ badane środowisko, że bardzo łatwo stać się bezdomnym. Jest to łatwiejsze niż się sądzi, choć pozornie wszystko oddala „domnych” od bezdomnych. Bezdomność dotyka najgłębszych wyobrażeń kulturowych o nas samych, naszej egzystencji i o innych ludziach. Jest to szczególny stan bycia, w którym zachodzi przewartościowanie bardzo wielu kwestii. Jest to przewrót życiowy, który polega na wyzbyciu się/ byciu pozbawionym tego, co kulturowo traktujemy jako metonimię człowieka - domu, czyli korzeni, przypisania, własnego miejsca w sensie fizycznym oraz (czasami) cielesności - w przypadku długotrwałej bezdomności następuje jej częściowa bądź całkowita niemal deprywacja ${ }^{2}$. Niektórzy z bycia klientem systemu pomocy czynią swój styl życia, co odbija się na ich postawie życiowej, zaś styl życia opierający się na wykorzystaniu środków i instytucji jest już także obecnie coraz częściej przekazywany z pokolenia na pokolenie.

Bezdomnych traktuje się w literaturze fachowej jako specyficzną kategorię wykluczonych. Samo to słowo, jak osądza Maciej Gdula, można zaliczyć do pojęć, „które zrobiły karierę”, w rezultacie stało się „rozmyte i wieloznaczne” (G d u la 2010: 78). Najczęściej poruszany jest problem, kto jest wykluczony: „dyskusje ogniskują się na sposobach mierzenia wykluczenia, dynamice i trwałości marginalizacji oraz identyfikowania obszarów, gdzie partycypacja społeczna napotyka na ograniczenia" (Gd u la 2010). Przywołany autor starał się np. ukazać rodzaj powiązań między mechanizmami wykluczania a mechanizmami porządku społecznego - wykluczenie cechuje według niego swoista „normalność” o tyle, o ile jest „uwikłane w odtwarzanie normalnych praktyk społecznych” (Gd u la 2010: 78).

2 Choć Jacques Pezeu-Massabuau twierdzi, że ciało dla bezdomnych ma zerowy stopień zamieszkiwania (za: S e g a u d 2007: 92). 
Do teorii wykluczenia wpisują się też teorie dewiantyzacji, w tym naznaczania społecznego i degradacji statusu; także teoria integracji vs dezintegracji, jak również dezorganizacji i reorganizacji społecznej; teoria marginalizacji społecznej oraz koncepcje upośledzenia i wykluczenia społecznego. Jerzy Kwaśniewski zaznacza, że „wszystkie one zakładają, stosując różną terminologię, że członkowie społeczeństwa przemieszczają się w strukturze społecznej i hierarchiach, mają przez to różny dostęp do dóbr i instytucji oficjalnego porządku społecznego. $\mathrm{Na}$ te procesy mogą mieć wpływ takie czynniki, jak: mechanizmy osobowościowe, społeczne i strukturalne" (K w a śni e w sk i 2010: 190).

„Wykluczenie” wyjaśnia stan rzeczywistości. Kryją się więc pod nim pewne diagnozy, opisy sposobów życia i postaw oraz objaśnienia mechanizmów społecznych i kulturowych. Nie jest to słowo obojętne, ma „wymiar normatywny (wyraża oceny instytucji [...]), i wymiar polityczny (postulaty zmian i reform), a kryterium podziału na te wymiary jest to, co chcemy dzięki nim osiągnąć" (S z arfen berg b.d.w.: 1).

Jak widać na podstawie powyższego zarysu kontekstu, w jakim występuje w nauce termin ,wykluczenie”, pewien rodzaj rozważań skupia się na zewnętrznych uwarunkowaniach zaistnienia marginalizacji. Powstają także prace, które traktują o aspektach wewnętrznych. Autorzy pragną wówczas oddać głos wykluczonym, uwzględnić ich perspektywę i ukazać, jak życie na marginesie wygląda w ich oczach i doświadczeniu. Do owego nurtu można zaliczyć m.in. pracę o „klasycznych” wykluczonych mieszkających na terenach zdegradowanych ekonomicznie Tomasza R a k o w s ki e g o (2009) lub szczególnie interesującą mnie pracę Patricka Declercka o doświadczeniu bezdomności paryskich kloszardów (D e c l e r c k 2004; jest to jedyna, przetłumaczona na język polski praca zagraniczna na ten temat oparta na sposobach badań stricte etnograficznych); ten postulat spełniałyby również niektóre prace z nurtu łódzkiej socjologii biedy ze szkoły Wielisławy Warzywody-Kruszyńskiej lub podejście prezentowane przez Elżbietę Tarkowską (War z y w o d a-Kru s z y ń ska 2001; Tarkow ska, Warzy w oda-Kruszyńska, Wód z 2003).

W znacznej części opracowań naukowych, nawet jeżeli autorzy decydują się w większym stopniu uwzględnić podejście partycypujące, łączy się obrazy od środka i z zewnątrz. Perspektywa, która scala te dwa ujęcia, jest bliska również mnie.

Miejsce prowadzenia badań (jedno ze schronisk dla kobiet bezdomnych z dziećmi i noclegownia dla kobiet w Łodzi) jest typowym trudno dostępnym układem społecznym (L o fl a n d i in. 2009: 51). To także miejsce trudne emocjonalnie, a ze względu na jakość przestrzeni jest obszarem kulturowo i społecznie problematycznym do oswojenia zarówno przez jego mieszkanki, jak i przybyszów z zewnątrz (np. przeze mnie). W praktyce oznacza to, że jest skomplikowane organizacyjnie, ponieważ składa się na nie siatka bardzo złożonych zależności; opanowane jest przez wewnętrzne napięcia (czasami konflikty), gdzie uderza mnie 
przede wszystkim gorycz i rozżalenie personelu i mieszkanek - każda grupa z innych przyczyn. Według mnie są to odczucia dominujące, które składają się na tamtejszą postawę. Schronisko i noclegownia (mieszczą się w tym samym budynku) są zaludnione przez osoby, które według autostereotypu, jaki wyraża część kobiet-rezydentek obu placówek, są odrzucane przez innych, niezrozumiane i niektóre z nich bardzo często dodatkowo ulegają społecznej wtórnej wiktymizacji. Przede wszystkim dlatego, iż wcześniej doświadczyły maltretowania i innych nadużyć ze strony partnerów lub pozostałych członków rodziny m.in. z powodu własnego alkoholizmu, czasami narkotyków, a najczęściej z powodu alkoholizmu mężczyzn. Dodatkową przyczyną wtórnej wiktymizacji - pogłębiającej rozgoryczenie i żal - jest fakt znalezienia się przez kobiety w schronisku dla bezdomnych oraz bycie samotną matką.

Nie jest to jednak teren, w którym mogłoby mi coś grozić fizycznie. „Jedynymi" stratami, które mogę odnotować w tej chwili, jest wzrost poziomu uczuć negatywnych (zwłaszcza goryczy i pewnego cynizmu). Jestem już, jeżeli mogę pokusić się o autodiagnozę na tym etapie moich działań, nieco „skażona” występującymi tam postawami. Podobnie jak Sharman L. Babior, prowadząca badania w tokijskim schronisku dla kobiet uciekających przed przemocą. Po pewnym czasie stwierdziła, że postawa spotykanych tam kobiet, polegająca na poczuciu braku wpływu i kontroli nad własnym życiem, zaczyna oddziaływać również na jej sposób funkcjonowania, patrzenia na świat, samoocenę, stosunek do innych itp. (B a bi or 2011: 29).

Lofland i Snow słusznie zauważają, że do problemów etycznych towarzyszących wszelkim badaniom, powinno się dodać refleksję, w której z jednej strony znajdzie się odpowiedź na pytanie, czy określone badania w ogóle mogą być przeprowadzone, biorąc pod uwagę dobro badanych, a z drugiej - czy powinny być one przeprowadzone przez konkretnego badacza. Dodałabym, że ze względu na jego dobrostan, w tym psychiczny bądź emocjonalny powinno się wziąć pod uwagę coś więcej niż tylko jego umiejętności zawodowe bądź ich brak. Takie podejście, pojawiające się w momencie wyboru lub zatwierdzenia danego tematu do realizacji, może wydawać się dość kuriozalne. Traktując jednak poważnie epistemologię naturalistyczną, czyli wyciągając konsekwencje z jej głównego założenia, że to badacz jest „narzędziem” poznania, zainteresowanie jego stanem nie jest fanaberią bądź solipsyzmem, a istotnym czynnikiem „pomiaru” prawdopodobieństwa przeprowadzenia badań zgodnie ze sztuką terenową, bez wyrządzenia szkody komukolwiek, w tym jemu samemu. Nie ma jednak jednego słusznego rozwiązania, jak ochronić badanych przed naszymi działaniami, a nas samych przed własnymi pomysłami - nie tylko w sensie błędu metodologicznego, ale np. przed podjęciem zbyt wielkiego ryzyka (od wystawienia się na niebezpieczeństwa fizyczne po chociażby uwikłania polityczne). Posługiwanie się w tym celu oceną zestandaryzowaną, ułożoną na podstawie parametrów przyjętych przez 
jakieś ciało decyzyjne, by ocenić stopień ryzyka zagrażającego jednej i drugiej stronie, wiąże się z mechanicznym i regulacyjnym wyobrażeniem powinności nauki i obowiązującym w jej ramach założeniem na temat sensowności poznawania określonych kwestii.

Istnieją zasady postępowania etycznego traktowane w antropologii kulturowej jako zasadnicze i niejako zrozumiałe same przez się. Są to: prawo badanych do informacji na temat celu, przebiegu i konsekwencji badań; zakaz wprowadzania ich w błąd; zapewnienie badanym poufności i prywatności oraz wymóg, aby badacz nie posługiwał się materiałem zdobytym nielegalnie, wymyślonym lub sfałszowanym (Christian s 2009: 219). Lofland i Snow trafnie zauważyli, że

nie próbując w jakikolwiek sposób umniejszyć znaczenia odnoszonych kwestii etycznych lub podważyć szczerości przepełnionych moralnym bólem wyznań badaczy, przestrzegamy przed poświęcaniem nadmiernej uwagi zagadnieniom etycznym oraz sumieniu, gdyż mogą się one przyczynić do zablokowania badacza do tego stopnia, że nie będzie on w stanie wypowiedzieć się na żaden temat niezwiązany z dylematami prowadzenia badań jakościowych. Uważamy, że prowadzenie badań terenowych rzadko stawia badaczy w sytuacjach trudniejszych niż sytuacje życia codziennego. Nie może być zresztą inaczej, gdyż praca w terenie nie lokuje się poza obszarem życia społecznego, lecz jest w nim osadzona, a dylematy etyczne [...] stanowią przedłużenie dylematów życia społecznego [wszystkie wyróżnienia - I. B. K.] (L o fl a nd i in. 2009: 120).

Można to podsumować: pokaż mi swoje dylematy etyczne, a powiem ci, kim jesteś w sensie społecznym, nie tylko prywatnym - skąd zatem przyszedłeś w teren.

Należy jednak pamiętać, iż sądy na temat krzywdy, szkody, uszczerbku itp., jakie są możliwe do wyrządzenia badanym, ulegają przeformułowaniom. Poza tym ważne jest, by odpowiedzieć otwarcie na pytanie, z jakiego światopoglądu etycznego i jakiej moralności wyrastają owe wyobrażenia ${ }^{3}$. Mamy także do czynienia $\mathrm{z}$ różnymi tabu występującymi w nauce. Są one równie zmienne w czasie i podatne na kulturowe oraz obyczajowe okoliczności, jakim podlegają sami badacze. Według niektórych istnieją tematy mniej bądź bardziej godne zainteresowania. Spośród mniej godnych także niepoważne, ośmieszające lub obrażające powagę etosu danej gałęzi wiedzy. Mogą to być zarówno zagadnienia niewspółbrzmiące z aktualną (doraźną) polityką naukową, jak i z modami intelektualnymi, którym hołdować mogą równocześnie bądź rozłącznie decydenci i szeregowi naukowcy. Do tych kwestii zaliczyć trzeba problem z określeniem wybranych zagadnień jako za „mało naukowych” lub zagrażających regresem bądź nadużyciami wobec osiągnięć danej nauki etc. W tym miejscu warto przywołać idee Thomasa Kuhna, że tego typu zastrzeżenia są de facto pytaniami o sens i zakres naukowości. Argumenty zaś wysuwane przeciw określonym propozycjom ba-

3 Patrz Kaniow ska 2010: 8 lub np. Li n c o ln 2009; choć sytuacje opisane przez Yvonne S. Lincoln zupełnie nie przystają do kontekstu uprawiania nauki w Polsce, jest to jednak tekst bardzo ciekawy, ponieważ obnaża mechanizmy ideologicznej kontroli uprawiania badań. 
dawczym są zazwyczaj wyrazem życiodajnych konfliktów w łonie nauki - sporem o przesunięcie bądź o zmianę definicji owej naukowości lub szczegółowego pola badawczego; dowodem otwarcia na „nowe” zarówno w procesie poznania, jak i na poziomie rezultatów poznania. Jestem ostrożna wobec zbytniego zaufania kodeksom, które mają tendencję do uściślania rozstrzygnięć w automatyczny sposób, jak również wahałabym się przed bezwarunkowym zaufaniem strażnikom zasad. Nie posunęłabym się jednak tak daleko, by opowiedzieć się po stronie „liberalizmu” w nauce. Drogę środka rozumiem jako zachowanie czujności (lecz nie przeczulenia) wobec wszelkich ewentualnych nadużyć wobec badanych i nas samych. Przede wszystkim zaś nie należy negować praktyk „odsłaniania swojej duszy", co w języku mniej poetyckim określa się w nauce jako pozycjonowanie. Powinno włączyć się ją w proces dociekania „stosowanych procedur”.

Stosując się do powyższego zalecenia, chciałabym wyjaśnić, że nie zdecydowałam się ,grać roli” bezdomnej i wracam do domu po każdorazowym pobycie w schronisku. Sama mogę regulować częstotliwość i długość pobytów wśród kobiet, co także związane jest z moimi zobowiązaniami wolontariackimi. Być może $z$ tego powodu nie doznałam jeszcze uczucia, że moja wytrzymałość jest wystawiona na zbyt wielką próbę. Moje wrażenia tylko w niewielkim stopniu współbrzmią z odczuciami badaczy, którzy wybrali podobny teren do mojego, ale inny sposób badania. Nie posunęłabym się więc tak daleko, by stwierdzić - wzorem Lindy Dunn zajmującej się kobietami-ofiarami przemocy - że popadam w depresję i bezsenność; lub za przykładem Marthy Copp - pracującej wśród osób niepełnosprawnych fizycznie i umysłowo - że cierpię na poczucie winy wynikające z mojej lepszej kondycji i pozycji społecznej w porównaniu z badanymi (L ofla nd i in.: 2009, 55). Przede wszystkim odczuwam coś, co nazwałabym zżymaniem się na niespójny system pomocy, a co nie jest winą osób pracujących w tym sektorze, lecz wadliwego prawa. Po drugie, bliskie jest mi odczuwanie bezradności, kiedy niektórzy nie chcą sobie pomóc lub nadużywają pomocy. Mają jednak zarówno prawo do korzystania z różnych form pomocy, w tym na swój sposób, jak i do odmowy jej przyjęcia. Sytuacje tego typu skłaniają do wyrobienia w sobie coraz większej elastyczności i braku zdziwienia czymkolwiek (co zaprzecza zdecydowanie archetypicznemu „dziwieniu się” antropologa; ów brak wątpliwości być może oznacza, że jestem coraz „mniej” antropologiem, a „więcej” - osobą działającą w ramach określonego systemu ukierunkowanego na pomoc).

Powód, jaki stał za moją decyzją, by nie wcielać się w bezdomną, wiązał się z moim rozumieniem postępowania wobec tych badanych. Stan, w jakim się znajdują (różne fazy bezdomności i „,domności”), dla większości z nich, z którymi udało mi się nawiązać kontakt, nie jest sposobem życia wybranym samodzielnie lub z rozmysłem - są ofiarami okoliczności. Były to osoby objęte często specyficzną socjalizacją i akulturacją, co ukazują czasami ich opowieści na temat życia, jakie wiodły, i na temat relacji, jakie łączyły je i łączą z najbliższymi. Życie to 
można określić jako bordeline - ryzykowne, niedające poczucia bezpieczeństwa, oparte na relacjach zaburzonych i degradujących (społecznie, emocjonalnie, wewnętrznie i zewnętrznie - także pod względem niedostatków zasobów materialnych). Nie miały więc często świadomości, że w konsekwencji pewnych zbiegów okoliczności, własnych wyborów lub zdania się na nurt określonej egzystencji, zostaną rzucone właśnie $\mathrm{w}$ to miejsce $\mathrm{i}$ obdarzone stygmatem bezdomności. Co gorsza, wiele aspektów życia społecznego obsadza w roli „klienta” systemu pomocy określone kategorie osób, wykazując elastyczność granicy dzielącej „domność” od bezdomności. Jednak los pewnej części poznanych kobiet jest odwracalny, choć dochodzimy tu m.in. do kwestii wydolności krajowego systemu opieki, co nie będzie poruszone przeze mnie w tym tekście wprost. Skoro nie jest to ich samodzielny wybór, wcielanie się w bezdomną byłoby czymś, co mogłoby im nawet uwłaczać: nie są urodzone bezdomnymi, nie żyją w „kulturze bezdomności”, która jest jednostką endogamiczną z tradycją lokalną, terytorium, historią itp., ani nie jest to byt sui generis funkcjonujący pod nazwą własną (choć to stwierdzenie jest problematyczne w kontekście przekazywania dzieciom wzorów życia i zachowania „klienta” instytucji pomocy; w schronisku przebywają np. dzieci, które nie znają innego „domu” poza tą instytucją, ani nie obserwują innych sposobów utrzymania się, oprócz korzystania z zasiłków - ich matki nigdy nie pracowały, podobnie jak nie pracowały już ich babki). Bezdomność jest przejściowym stanem, mimo że może trwać latami i często dla niektórych jest ostatnim etapem życia, zaś dla kilkorga dzieci ze schroniska - pierwszym i na razie jedynym. Zazwyczaj kobiety chcą porzucić bezdomność, która bardzo mocno naznacza i minimalizuje jednostkę, także w jej własnych oczach. Najsilniejszą barierą pozostaje jednak strach przed poradzeniem sobie i wpadnięciem znowu (najczęściej) w alkoholizm.

„Granie” bezdomnej, czyli szukanie wyznaczników jej „habitusu” i przybranie go na czas badań (por. Clifford 2004), było i jest więc dla mnie nie do przyjęcia w przypadku wcielenia się $\mathrm{w}$ rolę szukającej dla siebie schronienia w noclegowni lub w schronisku bądź osoby żyjącej na ulicy (byłby to wówczas dowód na cechującą również mnie osobowość bordeline ze względu na podjęcie tak skrajnego ryzyka w zestawieniu z moją zwyczajną sytuacją życiową). Badacz jest rzeczywiście, co uwidaczniają np. moje działania, narzędziem poznania, a przebieg poznania oraz jego ramy powinien poddawać ścisłej kontroli i dostosowywać do wielu okoliczności, w tym do samego siebie. Miałam i mam nadal bardzo silne przekonanie, że byłaby to gra w sensie: udawania, przebierania się, szczególnie ze względu na pozostawiony sobie przywilej powrotu do domu w momencie niebezpiecznym lub trudnym do zniesienia, podczas gdy prawdziwa bezdomna nie ma dokąd uciec. Poza tym, wchodząc w taką rolę, mogłabym wybrać dla siebie także dogodny moment wcielenia się w ,postać” bezdomnej: od pory roku po własny cykl fizjologiczny (przeszkadzające czy pomagające znieść 
trud życia w noclegowni lub na ulicy). Rzeczywiste bezdomne nie wybierają sobie takich okoliczności. Jak zatem w tak zarysowanej sytuacji etycznej „grać” emocje bezdomnej, „wcielać się" w nią? Jestem przekonana, że jest możliwe nawiązanie relacji z badanymi pomimo braku zakorzenienia $\mathrm{w}$ ich grupie lub mimo niemożności zupełnego przeniknięcia do ich sposobu życia (zawsze osiąga się pewną granicę, m.in. granicę empatii; patrz K ij e w s ka, K u źm a 2009).

Posługuję się określeniem „relacja dialogiczna”, choć być może jeszcze lepszy byłby termin „kontakt dialogiczny” (za zbyt mocne uważam „dialog” lub „wspólnota dialogu”). W pewnych okolicznościach pojęcia „relacja” lub „kontakt" oznaczają maksimum możliwości, jakie można wydobyć z przestawania z badanymi. Czy odpowiedzialność za nawiązanie „tylko" relacji w porównaniu z „wejściem w dialog” lub zawiązanie „wspólnoty” leżą po stronie badacza? Czy może byłby to dowód, że w moim przypadku badania te nie powinny być prowadzone ze względu na brak kwalifikacji (od osobistych po warsztatowe), czy też powinnam ich zaprzestać, ponieważ teren „nie rokuje” (jest mało podatny na otwarcie)?

Pozornie pytania te wydają się słuszne i jako takie wymagałyby poważnych odpowiedzi, można jednak zastanowić się, czy są to naprawdę pytania właściwe? Wchodząc na drogę „hermeneutyki podejrzeń” i stosując ją wobec dialogu, ujawnia się niebezpieczna refleksja. Taka, którą wyartykułował np. Jacek Kołtan: „przekonanie, że jesteśmy zdolni zrozumieć, okazuje się mniej czy bardziej nieuświadomioną wolą władzy - jest oznaką ignorowania faktycznej inności Innego, albowiem niemożność zrozumienia jest elementarna dla i we wszelkiej relacji, ale być może też bardzo skutecznie wypierana" (Kołtan 2011: 109). Założenie o porozumieniu oparte jest na wyobrażeniu, że każda ze stron dialogu jest zanurzona w tej samej strukturze znaczeniowej świata (K ołt a n 2011: 112). To jednak tylko wyobrażenie. Zamiast hermeneutyki należałoby mówić o hermetyce. Ujawnia się ona najmocniej w momentach szczególnej nieprzenikalności, jaką nasycone są graniczne odczucia i sytuacje oparte m.in. na strachu, bólu, radości, cierpieniu, szoku, kontakcie z czymś nieznanym, życiu religijnym itp. Kołtan zauważa, że wówczas - w chwilach spotkania z Innym i niecodziennym - na styku doświadczeń i horyzontów wytwarza się dodatkowa przestrzeń. W miejscu tym pojawiają się napięcia i konflikty. Oznaczają niemożność sprowadzenia różnych horyzontów do jednego - podzielanego z Innym według hermeneutycznego ideału porozumienia i zrozumienia. Zamiast zlania się horyzontów, mamy do czynienia z ich zderzeniem i zazębianiem: „żyjemy w świecie dialektyki bez możliwości i potrzeby syntezy rozumianej tu jako partycypowanie w jednym wspólnym świecie perspektyw aksjologicznych czy też znaczeniowych w szerokim sensie tego słowa" (Kołt a n 2011: 117). Jakie jest wyjście z owej sytuacji? Hermetyka odróżnia się od hermeneutyki tym, że nie oznacza wejścia w krąg wspólnoty dzięki doświadczeniu porozumienia i dialogu, ponieważ od razu odrzuca obciążające 
wszelki kontakt skryte założenie, że aby zrozumieć, trzeba „uswojszczyć” Inność. Hermetyka urealnia nasz kontakt z Innym - poprzez niego przyglądamy się sobie, co może czasami doprowadzić do podważenia własnego stanowiska. W ten sposób następuje otwarcie na Inność - otwieramy szczelinę, by Inność mogła zaistnieć. Nie chodzi o „poszerzenie” siebie samego i dołączenie cudzej perspektywy do swojej, chodzi o potraktowanie siebie jak Obcego. Celem jest odczucie własnej nieprzenikalności - poczucie swojej obcości wobec i dla samego siebie. W ten sposób mogłoby się otwierać miejsce dla Obcości w ogóle oraz zrozumienie jej sensu i właściwości Innego, Inności. Jak się wówczas ukonstytuować na nowo? Czy powrót „do siebie” jest możliwy? Dokąd kierować kroki po tym doznaniu, jakie zachodzi w obliczu Innego i zarazem własnej inności? Uzmysławiamy sobie własne „Ja” jako zintegrowane i ciągle osobne, zaś dzięki podważeniu go przez nas samych jest już inne.

Przekonanie o możliwości nawiązania kontaktu z badanymi pomimo hermetyczności grupy wynika z moich wcześniejszych doświadczeń badawczych, zwłaszcza uzyskanych podczas badań wśród mniejszości niemieckiej i żydowskiej w Łodzi. Również wtedy zarówno z przyczyn etycznych, jak i kulturowych (zamknięte i małe grupy) nie mogłam się w nie wtopić. Mimo to sadzę, że poznanie i zrozumienie nie jest zupełnie chybione, choć grupa pozostała do końca grupą oddaloną, szczególnie że nie było możliwe spędzanie z nimi każdego rodzaju aktywności, jaką praktykowali. Zatem nie było mi dane wrosnąć w ich środowisko, przebywać wśród nich długo, włącznie z możliwością ukrycia się na jej obrzeżach. Podstawowym powodem utrudniającym szczególnie tę ostatnią kwestię, była postawa badanych - nie było to możliwe dla nich, ponieważ ze względów np. religijnych chcieli zachować odrębność; pragnęli być sobą, czyli być kimś innym od reszty. Tym samym podkreślali dzielące nas różnice. Według nich różnice wynikały po pierwsze, z naszego odmiennego społecznego statusu - przyszłam do nich jako badaczka. Po drugie - wypływały z naszej obopólnej inności kulturowej - byłam dla nich obca nie tylko dlatego, że byłam badaczką. Obcość ta wiązała się z moją inną przynależnością kulturową i odbijała się na jakości i rodzaju kontaktu, jaki istniał między nami i toczył się wedle zasad określonych przez daną grupę. Nie stawał więc przede mną dylemat, o którym można przeczytać w tekstach badaczy rozważających kwestię negocjowania obecności w terenie - dotyczący partycypacji badanych i badacza we wzajemnych relacjach oraz stosowania większej lub mniejszej przemocy symbolicznej (patrz np. Wróblewski, S ochacki, S t e bli k, red. 2010 lub B u lińs k i, K a ir sk i, red. 2011). Nie sposób nie zadać tutaj pewnych pytań (choć zostawię je bez odpowiedzi wprost, ponieważ sytuacje, jakie ja poznałam podczas prowadzenia badań, nie pozwalają mi jej udzielić): w czym miałby kto partycypować i na którym etapie badań oraz kto i kiedy stosuje jaki rodzaj przemocy symbolicznej? Wydaje mi się, że pewne słowa (partycypacja, przemoc symboliczna) stały się wytartymi metaforami i są traktowane 
sztampowo, a choć same z siebie dają wiele możliwości analitycznych trudno wyjść obecnie poza ogólniki, gdy się nimi operuje. Czytając aktualne rozważania na temat badań terenowych, pojawiające się w literaturze polskiej i obcej, mam wrażenie, że wszyscy pracujemy w tym samym miejscu i ten sam sposób. Wynika to najprawdodpobniej z tego, że wykształcił się już pewien dyskurs ramowy „pozycjonowania" badacza terenowego (może tylko w Polsce?).

Zatem w przypadku badań wśród mniejszości w Łodzi lub prowadzonych w schronisku i noclegowni jestem kimś, kto nie ma zbyt wielu okazji, by rozmawiać otwarcie bądź stosować „tajne” wybiegi. W sytuacji działań toczących się wobec grup hermetycznych i naznaczonych w różny sposób, a chcących zachować odrębność lub negujących własną Inność (pochodzącą nie z ich wyboru i samoidentyfikacji, ale w wyniku zewnętrznej stygmatyzacji), badanie polega na adoptowaniu się do sytuacji i szukaniu języka, który nie rani. Język taki nie powinien włączać jednostek i grup w niechciane przez nie konteksty, zatem nie może ustanawiać znaku równości (co kryje się w skrytykowanej idei hermeneutycznego dialogu), albowiem zabieg ten może być odrzucany przez grupę. Język powinien wykazywać zrozumienie dla osobności - czasami niechcianej, w tym wstydliwej dla badanych, czasami pożądanej i strzeżonej (z tego powodu powinno się przyjąć ich milczenie o sobie, niechęć do odkrywania się i dzielenia się sobą).

Mój kontakt $\mathrm{z}$ bezdomnymi oparty jest na poznawaniu ich na terenie schroniska i noclegowni, nie na ulicy (choć czasami rozpoznajemy się z niektórymi kobietami „w mieście”). Badane przeze mnie bezdomne i obraz bezdomności, jaki uzyskuję, są ograniczone ramami instytucji, w jakiej kobiety znajdują doraźne lub stabilniejsze (nawet paroletnie) schronienie. Ta bezdomność jest specyficzna i z pewnością jest inna od tej, którą mogłabym uzyskać na podstawie badań nawet tych samych osób, lecz obserwowanych w innym otoczeniu.

John L o fla nd i in. (2009: 54-55) opisują badaczkę, która „zainstalowała się" na oddziale onkologicznym i przerwała w którymś momencie swoje naukowe próby, ponieważ nie była w stanie znieść pobytu w tamtym miejscu. Nie mogła „udawać” chorej i wtopić się w tego rodzaju tło na sposób jakże charakterystyczny dla badacza jakościowego i zarazem na sposób często oczekiwany przez naukę inspirowaną etnografią lub będącą etnografią. Nie sądzę jednak, aby takie wyobrażenie o prowadzeniu badań było kiedykolwiek możliwie: czy w epoce Malinowskiego, czy też obecnie. Wydaje mi się, że jest to jeszcze trudniejsze, kiedy teren oznacza najczęściej nasz kulturowy „dom” lub przynajmniej „sąsiedztwo". Obejmuje on przestrzenie i kulturowo najbliższe nam otoczenie, wywołując czasami efekt ,interferencji” mentalnej - nawet jeśli naprawdę światy badane są nam dostępne na wyciągnięcie ręki (pokrewne nam i dzięki temu mamy wrażenie, że ich obcość zatraca się w naszym rozpoznaniu rzeczywistości), mimo wszystko doświadczamy obcości uczuciowej i mentalnej. To właśnie może wydać się zaskakujące w przypadku, gdy im bliższy naszego domu róg, za którym znajduje się 
nasz teren. Obcość nie musi być jedynie wyrazem konstrukcji naszego antropologicznego patrzenia na świat (spojrzenia „egzotyzującego" - naszym podejrzanym dziedzictwem etnologicznym). Może być poczuciem odrębności i osobności, jakie wyrażają przed nami badani, o czym wspomniałam powyżej, a co skrywa się pod pozorną bliskością relacji i punktów odniesienia zachodzącymi między nami a nimi.

Powyższe przekonania są owocem moich własnych doświadczeń badawczych wśród grup także w pewnym sensie marginalizowanych w Łodzi, takich jak społeczność żydowska i niemiecka. Dzieląc się powyższą opinią, nie aspiruję do wyczerpania innych możliwych stwierdzeń i doświadczeń. Jest mi w tym momencie blisko do zdania Tomasza Rakowskiego, kiedy prezentował pierwsze refleksje po badaniach nad biedą, że postulat jak najdłuższego pobytu w terenie i wymogu, aby mieszkać tak jak Oni, żyć tak jak Oni - w perspektywie badań nad ubóstwem staje się warunkiem praktycznie niemożliwym do spełnienia (R a k o w s k i 2002: 67). Podobną postawę prezentuje także Hubert Wierciński zajmujący się antropologią medycyny (badał pacjentów objętych chemioterapią):

[...] antropolog postawiony w sytuacji uczestnika dramatu, którym niewątpliwie jest opowieść o chemioterapii, może jedynie słuchać i interpretować [...] Okazuje się bowiem, że współuczestniczenie i uwspólnienie doświadczenia w antropologii medycznej bywa bardzo trudne, czasem niemożliwe, wreszcie zupełnie niechciane - kto chciałby się znaleźć na oddziale onkologicznym i spróbować na własnej skórze kulturowości raka? (W i e r c iń s k i 2008: 52-53).

Istotne jest dla mnie posługiwanie się konstrukcją „,badania nad”, a nie „badania czegoś", mimo że niektórzy badacze interpretują tę pierwszą konstrukcję jako znak relacji władzy - dominacji antropologa nad terenem i badanymi. Dopiero mówienie o ,pracy z kimś”, czyli badanie współkonstruowane, powstające przy udziale badanych (w tym kontekście trudno ich nazywać „,badanymi”, są co najmniej rozmówcami), byłoby sygnałem dla wprowadzenia bardziej partycypacyjnego stosunku (por. B u lińs ki, K a ir s ki, red. 2011).

Jednak nie każdy teren, interesujący nas problem lub grupa mogą i chcą być badani przy swoim współudziale. Cóż to oznacza? W przypadku bezdomnych, jeśli negują siebie jako bezdomnych, trudno odwoływać się do tej afiliacji i na tej podstawie tworzyć wspólnotę sensów między badaczem a badanymi/rozmówcami.

Różnica między „badaniami nad” a „,badaniami czegoś” nie polega wyłącznie na ocenie czysto językowej poprawności. Poprzez zastosowanie partykuły „nad” wkraczam w strefę dystansu i pewnej niemocy etnografa. W moim przypadku teren wydaje się raczej czymś, co się obchodzi, „wizytuje” (za: R a ko wski 2002), przebywa na nim (jak na dryfującym statku) niż jest się w nim (w sensie: jest się gdzieś zagnieżdżonym, wrośniętym, oswojonym - przyzwyczajonym i opatrzonym zarówno w oczach badanych, jak i opatrzonym samemu z terenem). Ewentualnie, jeśli zdarza mi się być $\mathbf{w}$ terenie (tym obecnym), pobyt przypomina znalezienie się we wnętrzu labiryntu, choć bez nici Ariadny. „Odźwierni” 
niechętnie dzielą się swoją wiedzą i niechętnie widzą się w roli „odźwiernych”, ponieważ otwieranie drzwi komuś obcemu, kto prosi o wpuszczenia do świata, w jakim przebywają bezdomne, w dodatku - prosi o objaśnienie odwołując się do doświadczenia „odźwiernego", potwierdza tylko odrzucany przez taką osobę status jej bezdomności. Tymczasowym rozwiązaniem (i jedynym, jakie na razie dostrzegam jako wyjście z tej sytuacji), pozwalającym ufundować rodzaj „wspólnoty” między mną a niektórymi spośród nich, jest posługiwanie się przeze mnie szczególnym dyskursem, który będzie współbrzmiał z ich odrzuceniem siebie jako bezdomnych i wykluczonych oraz $\mathrm{z}$ ich niezgodą na bycie w miejscu wyizolowanym, specjalnie przeznaczonym dla nich, „obsadzonych” w roli bezdomnych. Jest to dyskurs „biorący w nawias” miejsce, gdzie są, a także to, kim są, przebywając $\mathrm{w}$ schronisku/noclegowni; dyskurs ten przyjmuje za dobrą monetę niemal wszystko, co słyszę i o czym jestem zapewniana lub informowana. Słowa i opowieści, jakie otrzymuję od większości kobiet, nie są celowo preparowanym kłamstwem lub chęcią specjalnego wprowadzenia w błąd, a pragnieniem (według mojej interpretacji) znalezienia się gdzie indziej, pokazania się jako ktoś inny osoba, która ma wpływ na własne życie, znajduje się po „dobrej” stronie, stara się, ale nie jest doceniana i od której wymaga się rzeczy prawie niemożliwych, a ci, którzy chcą je wyegzekwować (jak np. pracownicy socjalny monitorujący program wychodzenia z bezdomności) nie pojmują na czym „to wszystko” polega, ponieważ nie są na jej miejscu, nie doznali tego, co ona. Dyskurs ten w zasadzie neguje ich obecny status (status przeze mnie zastany), niektóre z nich nawet odrzucają takie słowa, jak: bezdomność, schronisko, noclegownia.

Według Loflanda i Snowa, radzenie sobie w terenie jest tym, co przede wszystkim robią antropolodzy w trakcie badań (L o fland i in. 2009: 90-122). Jest to integralny element prowadzenia badań, wręcz na tym one polegają. „Radzenie sobie" jest również dla mnie kluczowym pojęciem. Składa się z kilku elementów. Lofland, Snow i in. piszą o początkowym przeciążeniu informacją i dezorientacji badacza w chaosie kontaktów i danych; o lękach związanych z ujawnieniem przed badanymi swojej roli i ich reakcji na to obwieszczenie. Badacze mogą odczuwać dystans wobec badanych, co może się wyrażać poprzez tak skrajne odczucia, jak odraza, pogarda, poczucie wyższości lub nienawiść. Są to uczucia niezwykle rzadko ujawniane, mogą wiązać się z brakiem empatii lub niemożnością jej okazania (z różnych przyczyn), zatem poważnie utrudniać pracę badawczą, wręcz dyskwalifikować badania do realizacji i badacza do ich prowadzenia, ale niekoniecznie muszą dyskwalifikować badacza jako człowieka (patrz kazus Declercka: Declerck 2004). Badacze mogą również przyjąć postawę polegającą na „poddaniu się" badanym (L ofland i in. 2009: 93). Naukowcy mogą mieć też poczucie marginalizacji - są odsuwani lub nie udaje im się znaleźć wspólnego języka, występuje brak zaufania we wzajemnych kontaktach. Czasami badacz nie może i nie chce poddać się wymogom grupy, zbyt wiele ryzykować, 
zwłaszcza jeżeli przyjął strategię badań niejawnych (np. działając w grupie przestępczej lub żyjącej na granicy prawa bądź gdy bada grupę hermetyczną i trudno mu znaleźć do niej dostęp albo gdy zagrożona jest jego tożsamość, choćby gender-owa). Do rzadkości bowiem należą takie sytuacje, jakie przydarzyły się m.in. Geertzom na Bali, lub mniej znana przygoda Snowa i Andersona ${ }^{4}$ (L o fland i in. 2009: 98). Bardzo niewielu naukowców dotyczą tego typu spektakularne przełomy. W momencie pojawienia się uczucia sympatii i utożsamienia się badacza np. z jakimś fragmentem życia, poglądów itp. badanych zmienia się jego stosunek wobec nich (i vice versa), zmienia się także pogląd na temat badań, w tym stosunek do własnej roli.

W niniejszym tekście chciałabym się skupić na wybranym zagadnieniu, które włączyłabym do procesu radzenia sobie. Zagadnienie to przynależy również do procesu radzenia sobie badanych z obcym (którym jest np. badacz) oraz radzenia sobie przez nich z samymi sobą. Interesuje mnie rola milczenia i unikania kontaktu (wyrażające się poprzez zapadanie ciszy, trwanie w ciszy). Jeśli bowiem, według Loflanda $i$ in., podstawowym i pierwszym problemem $z$ radzeniem sobie $\mathrm{w}$ terenie jest natłok informacji, z jakimi musi uporać się badacz, moje doświadczenia z tego etapu pokazują, że czasami owego nadmiaru danych nie musi tworzyć faktyczna liczbowa przewaga czegoś, co jest uchwytne np. w postaci notatek z konkretnych słów itp. W moim przypadku ów nadmiar tworzy coś, co ,jest” i występuje w przewadze, choć ma właściwość porównywalną do czarnej materii - jest nieartykułowaniem, odwracaniem wzroku, niemówieniem.

\section{NIEMY KONTAKT - UWARUNKOWANIA RELACJI DIALOGICZNEJ}

Niemota - bezgłośność, niemożność wypowiedzenia się, ponieważ nałożono na nas blokady zewnętrzne; defekt bądź niedostatek różnego rodzaju lub dobrowolnie przyjęta asceza i odizolowanie się od innych, od świata, także od siebie poprzez niezabieranie głosu.

Agnieszka Kościańs ka (2009: 113-120), przytaczając sens ciszy rejestrowanej w terenie przez różnych badaczy, zwraca uwagę, iż popadanie w milczenie - zachowanie ciszy może być swoistą formą oporu osób, klas, warstw postawionych niżej, wyrugowanych ze sfery publicznej, zepchniętych do kulturowej niszy symbolicznej. Kwestia mówienia, milczenia i tego, czego dotyczą, jest częsta w badaniach zorientowanych na studia kobiece lub problematykę różnych mniejszości, także w kontekście studiów opartych współcześnie na świadomości postkolonializmu. Cisza i milczenie, otaczające w określonej społeczności wybrane grupy, mogą się przekładać w prawie zwyczajowym na brak ich prawa do

${ }^{4}$ Badacze zostali aresztowani wraz z bezdomnymi, którzy po tym epizodzie nabrali do nich zaufania i stali się ich rozmówcami. 
głosu i wypowiadania się oraz na lekceważenie słów takich osób i nieliczenie się z ich opiniami. Tym samym sprzyja określeniu ich jako milczących/bez głosu/ niemych (muted groups, za: K o śc i a ń s k a 2009: 114). Utrzymywanie milczenia może być także postawą obronną, np. chroniącą przed badaczem. Byłaby to zatem konkretna forma, jaką przybiera chęć wycofania się przed wszelkim innym/ obcym. Milczenie z jednej strony otacza ochronnym kokonem tych, którzy je zachowują: nie mówią - bronią się, kiedy zaś nie mówi się o nich, może to oznaczać niezwracanie na nich uwagi, aby ich chronić (jak chociażby pomijanie milczeniem własnych żydowskich korzeni praktykowane w niektórych środowiskach znanych mi z autopsji albo niezdradzanie głębokiego powodu, który przywiódł kogoś do schroniska, a zdanie się na kwalifikację systemową: eksmisja, ,jestem z przemocy", długi etc.). Z drugiej strony odmowa udzielenia głosu oznacza czyjąś społeczną nieważność. Milczenie może również ochraniać przed kontaktem $\mathrm{z}$ tak naznaczoną grupą lub jednostkami.

Cisza, przypatrując się jej w warunkach kontaktów interpersonalnych i komunikacyjnych, jest brakiem działania (O l e a r c z y k 2010: 24). Może być uznana za zatajenie czegoś, niedzielenie się wiedzą lub uczuciami z innymi, ukrywanie się.

Olearczyk odróżnia ciszę od milczenia, przeprowadzając między nimi linię podziału opartą na dychotomii obiektywne - subiektywne. Odwołując się zaś w tym miejscu do ustaleń językoznawców (patrz: Han dke 1999a: 12-13), że „milczenie” stanowi część ciszy, mieści się w niej, łączy się z terminami „drobny”, „miałki” oraz „głuchy”, czyli „,cichy”.

Cisza jest pewnym stanem zewnętrznym, sposobem istnienia materii (H a nd k e 1999a: 13), także - pewnym warunkiem i okolicznościami, w które się zanurzamy, w nich przestajemy i które mogą rzutować na charakter naszego bycia i działania. Autorka stwierdza wręcz, że „wartością ciszy jest jej moc tkwiąca w możliwości opanowania chaosu" (O l e ar c z y k 2010: 25). Milczenie zaś utożsamia z subiektywnością (Handke zaś - z działaniem i uczestnictwem ludzi; H andke 1999a: 13). Może też być związane z dobrowolnym wyborem i przyjęciem postawy zdystansowanej. Zdarza się, iż jest postawą wymuszoną w milczenie da się kogoś wtrącić za pomocą okoliczności od niego niezależnych i niepożądanych. Oznacza to odseparowanie nas od kontaktów z innymi. Wówczas milczenie staje się przymusowym niedzieleniem się sobą, podczas gdy milczenie dobrowolne byłoby chronieniem się, wypracowaniem w sobie przestrzeni wolnej od innych, nie musi oznaczać negacji, ale wolność (jako wyjście poza relacje, nabranie do siebie i innych dystansu, uwolnienie się od zależności).

Wszystkie te stany, postawy i okoliczności mogą wypływać z bardzo precyzyjnych przesłanek: są nimi nasze cele i motywacje, wewnętrzne poczucie ładu lub chaosu, także poczucie braku kontaktu z otoczeniem i samym sobą. Popadnięcie w milczenie, czyli uprawianie ciszy, dotyczy najczęściej obszaru relacji międzyludzkich, co także podkreślała Teresa O le a r c z y k (2010: 38). Wiąże się 
z poczuciem izolacji: bycia niezrozumianym, lękiem przed innymi, przed sobą lub w związku z czymś. Wypływać może z niezdolności do wypowiedzenia własnych potrzeb i poczucia, że jest się zbędnym, niechcianym, nieważnym, że jest się ciężarem i kimś obcym. Jednak milczenie i cisza są zarezerwowane dla tych, którzy są zepchnięci na margines - o czym była mowa. Mogą to być więc oznaki zaistniałej relacji dominacji i podporządkowania (co przywołana autorka przypomina powołując się na Martina Bubera).

Cisza, którą ktoś zachowuje, uwrażliwia nas również na wymiar intymności, tajemnicy i osobności jednostki - na zachowanie dla siebie czegoś, do czego mamy prawo wyrażające się poprzez odmowę głosu na dany temat (w tym milczenie o sobie). Milczenie jest antropocentryczne, cisza zaś może istnieć bez człowieka (O learczyk 2010: 51). Można milczeć wymownie i wtedy cisza spersonalizowana, mimo że pozostaje bezgłośna, aż krzyczy. Milczenie określić można jako „sztukę” i choć jest czymś, co oznacza zatrzymanie w sobie/dla siebie słów, sądów, komunikatów, jednak „mówi” emocjami: wrogością, obojętnością, przyjacielskością lub innymi. Rozpoznajemy je po wyrazie twarzy lub samych oczu, napięcia mięśni i także innych gestów oraz działań kulturowych (Ko ściańska 2009).

Umiejętność zachowania milczenia może być też warunkiem sine qua non umiejętności słuchania, czyli zdolności do przyjęcia słów kogoś innego. Wsłuchanie się w cudze słowa może oznaczać uwolnienie dla nich przestrzeni wewnętrznej, co symbolizuje wyciszenie się, zamilknięcie. Zamilknięcie nie oznacza tylko zapadnięcia się we własną wewnętrzną ciszę - może ukrywać się pod nim zgiełk lub pustka; to także broń, by chronić się przed zagrożeniem, jakim jest „przemoc symboliczna" w postaci niechcianej lub niezrozumianej rozmowy, wówczas milczenie takie byłoby niemówieniem.

Milczenie pozwala nie tylko wybrzmieć cudzym słowom, ale także je wchłania (o czym było już wcześniej): robi dla nich miejsce, również w sensie zachowania ich dla siebie. Jest zatem ściśle związane z postawą moralną - poszanowaniem innego, wyrzeczeniem się własnej perspektywy, choćby poprzez nieodzywanie się, niezabieranie głosu i pozwolenie, by cudze słowa wniknęły w naszą pamięć i aby były zapamiętane właśnie jako słowa innego, a nie jako nasza parafraza. „Człowiek, który umie zatrzymać słowa, nie potrzebuje ich wypowiadać, pozostaje w milczeniu pod wrażeniem słowa" (O le a r c zy k 2010: 64). Należałoby w tym momencie dodać, że pozostawanie pod wrażeniem słowa może być też wywołane złym, raniącym słowem (B u t 1 e r 2010). Kontakt z tak złą treścią może wywołać u niektórych rodzaj stuporu: uczuciowej lub mentalnej katatonii i cierpienia. Milczenie jest schronieniem - a często oznaką obojętności - przed tym, co się przydarza, zatem byłoby wewnętrzną ciszą, w jakiej ktoś trwa, która stanowi jego osobowy pejzaż.

Olearczyk posługuje się pojęciem „galenosfery”, czyli środowiska ciszy. Jest to całościowe środowisko życia człowieka złożone z wszelkich mikroobsza- 
rów ciszy, które budują pojedyncze życie. Różna jest bowiem waga i rola ciszy w domu lub w pracy, na ulicy, w miejscu rozrywek itp. Obszary ciszy, na które się natykamy, spełniają funkcję regulującą, ponieważ bez możliwości wejścia w ciszę występującą w tak różnych, jak wymienione powyżej, okolicznościach, byłoby trudno wygasić pewne bodźce, zatem odnaleźć równowagę wewnętrzną i zewnętrzną. Lecz permanentna cisza, co więcej - permanentne milczenie (trwanie bez żadnych bodźców, w zasadzie odcinanie się od nich, brak reakcji) może np. wypływać z motywacji duchowych i być jednym z ćwiczeń medytacyjnych, zatem czymś dobrowolnym. Jednak w schronisku dla bezdomnych, kiedy jest się jedną z wielu w otoczeniu pozostałych współmieszkanek i personelu (oraz wolontariuszki) milczenie wskazuje na niechęć do brania udziału w tamtejszym życiu. Wyjątkiem są może osoby, które cierpią na różnego rodzaju dysfunkcje psychiczne i choroby somatyczne, zatem milczenie i cisza, w jakich trwają, są elementami ich egzystencji, rodzajem konieczności, ale czasami świadomym i przemyślanym wyborem.

Milczenie „towarzyszy mówieniu, jest jego drugą stroną, jest też jego tłem” (Handke 1999a: 9). Milczenie rezydentek schroniska i noclegowni ma wiele wspólnego z „taktyką działania” (H a nd k e 1999a: 10). Taktyka ta jest wykorzystywana - stając się wspomnianym powyżej wymownym milczeniem - także w rytuale lub ceremonii oraz jest cechą wielu zwyczajów. Pewne grupy są uprzywilejowane do mówienia lub milczenia, inne - odpowiednio - do słuchania i zachowania ciszy albo mówienia w określonych warunkach, z precyzyjnych względów. Milczenie grupowe, jak zauważa Handke, może spajać ludzi we wspólnotę, może być także oznaką protestu lub oporu (jak marsze milczenia, ciche dni, odmowa zdradzenia źródła, kontaktu itp.; H and ke 1999a: 11). Jacek Juliusz Jadacki uważa, że milczenie realizuje się w sytuacji, gdy decydujemy się nie mówić, choć istnieje przymus lub uzus mówienia (J a d a cki 1999: 25). To także przejaw naszego stosunku do komunikowanej treści wypowiadanej przez nas osobiście albo przez kogoś innego (F a ry no 1999: 40). Komunikowalność milczenia - czyli coś więcej niż traktowanie go jako znaku, jak zauważa Jerzy Faryno, należy do nadawcy (podczas gdy cisza obejmuje i nadawcę i odbiorcę), nawet jeżeli to nie on pierwszy inicjuje kontakt. Zakładamy - zwracając się do jakiejś osoby - że może ona nam o czymś opowiedzieć, że jest zdolna do mówienia. Ktoś, kto mimo to zachowuje milczenie i nie zabiera głosu dosłownie też się wypowiada, choć jest to quasi-wypowiedź, „niewyartykuowany ekwiwalent wypowiedzi" (F a r y n o 1999: 41). Analiza Faryno jest tym cenniejsza, że wskazuje na pewną ważną zmienną dla dynamiki komunikacji - tylko ten, kto milczy w sytuacji rozmowy, wie kiedy rzeczywiście milczy, a kiedy po prostu nie mówi. Ten, kto wchodzi z nim w kontakt - milczący kontakt - nie potrafi tego rozpoznać i często milczenie traktuje jako niemówienie dyktowane cechami osobowościowymi (ponieważ ktoś może być milczkiem z natury lub kimś małomównym w określonych, np. deprymujących go, okolicznościach). Często 
stereotypowo uważamy, że pod milczeniem ukrywa się prawda albo że milczenie jest nieszczere (F a r y n o 1999: 44).

Osoba, która spotyka się z milczeniem i ciszą (w tym z bezruchem - brakiem wszelkiej reakcji) na wysunięte przez siebie zaproszenie do rozmowy, może poczuć się odrzucona. Trzeba jednak zrozumieć, co taka negacja znaczy, np. w schronisku i noclegowni.

Strategia komunikacyjno-egzystencjalna, jaka jest tam stosowana, redukuje słowo z tamtejszego sposobu bycia. Niedostatek komunikacji słownej może być odczytany jako oznaka odmowy podjęcia wysiłku zrozumienia nadawcy, także jako niechęć lub strach przed zmierzeniem się z czymś nowym (H a n d ke 1999b: 47-58). Należy jednak pamiętać, że życie w instytucjach zapewniających pomoc jest zawsze związane z mówieniem o sobie. Polega na odtwarzaniu własnej historii, nadaniu jej sensu i celu; polega też na nazywaniu i klasyfikowaniu wszelkich punktów zwrotnych we własnej biografii, która - co więcej - poddana jest ocenie, zestawiana ze standardową i w wyniku tych zabiegów okazuje się zazwyczaj nie pasuje do pożądanego wzorca. Powstaje w ten sposób schemat życia „na opak”, a zadaniem instytucji i jednostki, która wchodzi w orbitę działań systemu pomocy - jest przywrócenie „normalności” i ponowne wejście w standard. To, jak się żyje w obszarze oddziaływania instytucji (obejmującej nie tylko schronisko, ale też ośrodki wypłacające zasiłki, zapomogi itp.), jest poddawane werbalizacji, nazywaniu, klasyfikowaniu, sprawdzaniu. Oczywiście zdarzają się formy terapii pomagające wypowiedzieć się w sposób wolny - od siebie. W większości jednak praktyka komunikacyjna polega na „formatowaniu” osób objętych tego typu działaniem i na przekształcaniu ich w „klientów”, by nauczyć ich swoistej samoobsługi w sytuacji dramatu życiowego, jaki ich spotkał. Nikt nie neguje ich prawa do przeżyć, do złego samopoczucia ani do skrajnych emocji. Nikt też w instytucjach nie stwarza złudzenia, że oferowana pomoc jest adekwatna, szybka i wystarczająca dla wszystkich, a zasady według których jest udzielana, przewidują wszystkie możliwe konfiguracje życiowe, jak np. skomplikowane przypadki leżące na pograniczu różnych kategorii. Personel nie fałszuje obrazu pomocowej rzeczywistości. „Klienci” teoretycznie wiedzą zatem, co ich spotka, a później przekonują się o tym namacalnie, np. oczekują latami na lokal socjalny wraz z kolejnym dzieckiem, które nie zna życia poza schroniskiem.

Komunikacja jest zatem poddawana swoistej parametryzacji dokonywanej również przez współtowarzyszki w schronisku, ze względu na dostęp jednych lub też brak dostępu drugich do różnych form pomocy. Nieskrępowane słowo o sobie samej jest związane z zasobem samowiedzy i ze stosunkiem do własnych zarówno wcześniejszych, jak i obecnych doświadczeń; także z poczuciem bycia sobą (odczuwania samoakceptacji wobec siebie tu i teraz oraz dla siebie z przeszłości i posiadania wizji przyszłości). W sytuacji, w jakiej znajdują się kobiety w schronisku, tego poczucia bardzo często brakuje: życie jest sprowadzone głównie do 
bycia samowystarczalnym na poziomie egzystencji materialnej. Domyślam się, że dlatego większość z nich ucieka przed kolejną rozmową. Milczenie - w tej sytuacji oznaczające niemówienie - byłoby np. oznaką wycofania się w celu zachowania resztek autonomii. Lecz milczenie kobiet młodych (ok. dwudziestokilkuletnich), które należą do drugiego pokolenia klientek instytucji pomocy (czasami przyprowadzane są do schroniska przez matki - byłe podopieczne) i wychowujących już własne dzieci (rodzące się często w schronisku), wynika z nieumiejętności nazwania, czyli sproblematyzowania własnego życia w schronisku. Nie znają innego życia, o czym zatem mają mówić? Zarówno w ich biografię, jak i doświadczenie dzieciństwa, schronisko wpisało się jako „normalny” fakt. Jak się mają zatem ustosunkować do „skandalu” (jak to nazwałam) bezdomności? Poza tym, jaki rodzaj „bezdomności” reprezentują? W pewnym sensie są „domne”.

Praktyka polegająca na uciekaniu w milczenie została zaobserwowana przez badaczy analizujących zachowania werbalne dzieci, które w momencie przechodzenia przez określoną fazę rozwoju, polegającą na wyodrębnieniu się własnej tożsamości, były jednocześnie poddawane wielkiej presji (Maryniak 1999: 232). Milczenie było wówczas dla nich sposobem ochronienia się przed innymi strategią ratunkową.

W takiej sytuacji afonia oznacza

„Zwinięcie się” egzystencji. Na początku może być świadomą odmową komunikacji - milczeniem intencjonalnym, które wyraża bunt czy gniew. Lecz to wynikające z wyboru milczenie sprawia, że zdolność mowy staje się zbędna i zostaje zepchnięta na margines aktywności ciała, niejako uśpiona. Podobnie jak niewładna kończyna, która przestaje służyć realizowaniu zamysłów ciała, może zostać usunięta ze „schematu cielesnego” (M i c h a li k 2010: 212).

Gdyby sięgnąć w tym momencie do koncepcji Martina Heideggera, dotyczącej mowy i języka, sens niemówienia bezdomnych wiąże się także z ich negacją upubliczniania, wyrażania przed innymi własnego rozumienia świata, siebie i innych, pozostających z nimi w interakcji. Dla filozofa mowa to „możliwy do wysłowienia sens świata”, a także sposób usytuowania w świecie mówiącego - jego „,nastrojenie-położenie" (Michalik 2010: 179). Jak przypomina słowa Heideggera Joanna Michalik, ,językowy wskaźnik przysługującego mowie obwieszczenia położonego bycia «w» tkwi w intonacji modulacji głosu, w szybkości mówienia, W «sposobie wysławiania się»" (M i c h a li k 2010: 180). Mowę się zatem słyszy, rozpoznaje, identyfikuje z określoną jednostką. Symetrycznie - owa jednostka jest słyszana, rozpoznawana oraz identyfikowana przez kogoś innego jako ona, a dzięki temu dokonuje samoidentyfikacji. Brzmienie języka, sposoby artykulacji, dźwięki mowy kogoś jednostkowego są czymś swoistym, czego nie da się nauczyć poznając czystą teorię mówienia: trzeba je usłyszeć i nawet próbować imitować (np. ucząc się języka lub parafrazując - nie tylko słowa, ich sens, ale także rytm, w jakim ktoś mówi, jego intonację). Może to pomóc zrozumieć fenomen głosu, mowy i tego, co się mówi (dzięki temu zaś, zrozumieć fenomen języka). 
Ktoś, kto nie zabiera głosu dobrowolnie, jak robią to kobiety w schronisku - dosłownie nie wydając dźwięków, nie reagując werbalnie, nie podejmując wokalnego kontaktu przez dużą część dnia, kiedy zostają w budynku - wycofuje się tym samym z nazywania, przedstawiania i komunikowania świata i siebie światu. Nie oznacza to, że schronisko jest pogrążone w całkowitej ciszy. Jego mieszkanki operują językiem fatycznym, np. wychodząc na papierosa lub przebywając w tym samym czasie w kuchni; stosują także czasem zwierzenie przede mną, a czasami między sobą (zawiązują konwersacyjne „koalicje” dwu- bądź trzyosobowe).

Czyniąc z milczenia strategię postępowania, przede wszystkim jednak odmawiają istnienia samym sobie. Wynika to najprawdopobniej z miejsca i zarazem sytuacji, w jakiej się znalazły. $Z$ jednej strony miejsce to je w pewnym stopniu uratowało, z drugiej - ogranicza, zamyka, naznacza niechcianym stereotypem. Przebywają tam z kimś, kogo nie znają, nie chcą poznać - nie jest to wspólnota. Czy ich zapadnięcie w milczenie-niemówienie, można zinterpretować zgodnie z ideą Pascala Quinarda, którą przywołuje M i c h a li k (2010: 194), że mowa nas zawodzi, stawia nam opór i skrywa? Gdyby bowiem zaczęły mówić, może wówczas powinny zacząć od nazwania „początku”. Być może zamiast mowy usłyszelibyśmy więc krzyk. Jest to rzeczywiście częsty środek wyrazu, jaki można tam usłyszeć: kobiety komunikują się podniesionym tonem, przemawiają $\mathrm{w}$ ten sposób np. do dzieci i do siebie. Sądzę, że tamtejszy krzyk lub głos ustawiony na granicy krzyku oznacza coś więcej niż ton karzący albo wypowiedzenie na kogoś złości, lub wyżycie się. Rozmowy bądź komunikaty, które wymieniają prawie krzycząc do/na siebie, nie zawsze są awanturami, wzajemnym strofowaniem, wyrażaniem pretensji i okazywaniem agresji. Nie jest to personalne, choć czasami koncentruje się na wybranej osobie lub sytuacji. Krzyk, napięcie, ton wyższy i szybszy niż przyjęło się za normę konwersacyjną, są czymś charakterystycznym w sytuacji schroniska i obserwuję to od początku. Mieszkanki przekrzykują się nawzajem; panuje tam hałas wynikający z obecności na niewielkiej przestrzeni kilkudziesięciu osób (w tym małych dzieci), co słychać szczególnie w określonych porach dnia: rano i od popołudnia do wieczora.

Wedle koncepcji Maurice'a Merleau-Ponty'ego, ,przyswajanie języka, form jego artykulacji, nadaje określony kształt ekspresyjnej sile ciała. W ten sposób język przekształca «naturalne» dyspozycje, sprawia, że w ciele «odkłada» się sens" (Michalik 2010: 204).

Krzyk i niemówienie składają się na tamtejszy habitus kobiet - od ciała po sposób bycia. Te dwa zachowania uzupełniają się i stają się cechami zasadniczymi dla ich postawy schroniskowej. Inna interakcja werbalna jest trudna, o ile możliwa. Mój udział w ich komunikacji jest zatem również wejściem w afonię lub w krzyk.

Co bowiem zazwyczaj robi antropolog? Czy rzeczywiście przede wszystkim pisze (G e e r t z 2005: 35)? W ten sposób antropologia rozgrywa się przy biurku - symbolu umysłu badacza. Może raczej wysłuchuje? Takim byłby np. antropo- 
log empatyczny (Ka u fmann 2010: 79). Wówczas antropologia działaby się $\mathrm{w}$ momencie przestawania $\mathrm{z}$ badanymi, zaś pisanie byłoby czynnością uwiarygodniającą.

Najczęściej zanim antropolog napisze i wysłucha przede wszystkim mówi, tzn. zadaje pytania. Tego się uczymy, do tego przygotowują nas wieloletnie zajęcia na studiach i potem własna praktyka. Ucząc się specjalnego, antropologicznego pytania-przedstawiania-przekonywania, rzadko uczymy się świadomie angażować w taki rodzaj bycia w terenie, aby wsłuchiwać się w to, co dzieje się dookoła nas. W to, co słychać samoistnie i co „się samo" wypowiada bez naszej ingerencji i nadania celowości poprzez postawienie pytania, które ukierunkowuje, a raczej przekierunkowuje. Mamy tendencję do traktowania źródeł wywołanych jako uprzywilejowane. Jednak otaczają nas niemal czyste źródła zastane w postaci słów, stwierdzeń, pogwarek, rozmówek, krzyków, paplania i tym podobnych, wraz z towarzyszącymi im performensami. Wartościowy jest jednak raczej dla nas bardziej kontakt sprowokowany, czyli specjalne słowa adresowane do nas przez badanych. Słowa te są reakcją na pytanie wytrącające $\mathrm{z}$,niewinności” rozmowy i przechodzą w taką formę konwersacji, która jest rozmową celową. Co ważne, rozmowę taką kontroluje nie tylko etnolog, mimo że najczęściej to on ją inicjuje, prowadzi i kończy. Złudzeniem jest przezroczystość codziennej konwersacji, która nie jest wystawiona na obce spojrzenie i ucho przydające jej wyjątkowości. Reguły istnieją w każdej sytuacji, choć podczas szumu konwersacyjnego codzienności pozostają może lepiej ukryte, stwarzając złudzenie, że komunikacyjny świat toczy się sam. W obecności obcego, który zadaje pytania (dopytuje, chce wiedzieć, a dzięki tej wiedzy zrozumieć), zasady się ujawniają i powraca świadomość enuncjacji.

Sytuacja schroniska obliguje do takiego sposobu bycia, który John L o f l a n d i in. (2009: 107) nazywają ,niewzbudzającym obaw”, czyli okazywaniem szacunku i uprzejmości (co brzmi banalnie). Pod tymi określeniami autorzy rozumieją zachowanie „niezagrażające badanym”, nie mają jednak na myśli zagrożenia fizycznego, ale takie zachowania badacza, które nie byłoby wymierzone w sposób bycia badanych, ich postawy, poglądy lub zachowania. Do uprzejmości i szacunku należy przede wszystkim powstrzymanie się od oceniania badanych. Postawa naturalistyczna co prawda nie polega na ukrywaniu naszych poglądów, ale na ujawnianiu ich wówczas, jeśli pozwala na to sytuacja i nie może się to równać z potępieniem badanych. Powinniśmy zachować także czujność wobec własnego braku zainteresowania badanymi i okazywania tego.

„Najlepiej jest akceptować ludzi takimi, jakimi są, i nawet w myślach nie oceniać ich zachowań, przekonań oraz stylu życia" (Bruce Berg, cyt. za: L o fla nd i in. 2009: 107); ,należy «słuchać dobrze i z szacunkiem»” (Barbara Herman, cyt. za: L o fl a n d i in. 2009: 107). „Dobre słuchanie” według przywołanych autorów oznacza: wspieranie, serdeczność, zainteresowanie, niekonfliktowość, uprzejmość, rozumienie, współczucie. $\mathrm{Z}$ owych cech moją uwagę przyciąga aktualnie 
„zainteresowanie”. W warunkach schroniskowych, a szczególnie noclegowni (gdzie panuje jeszcze większa przygodność kontaktów), zainteresowanie może być łatwo zinterpretowane jako wścibstwo lub nachalność. Zatem potraktowane jako „wzbudzające obawy”, że ktoś stał się celem uwagi osoby obcej, a strategia kobiet polega na byciu niewidzialnymi (nie patrzy się w oczy obcej i innej, nie słucha się, co mówi poza kwestiami związanymi bezpośrednio z ich conocnym pobytem albo własnymi sprawami). Moje zainteresowanie musi być zatem adekwatne do potrzeb sygnalizowanych przez określoną osobę i nie wybiegać poza jej zainteresowanie. Tamtejszy „dialog” badawczy, który jest moim udziałem, polega zdecydowanie na „rozmowie w działaniu” (L o fl a nd i in. 2009: 131). Jest to konwersacja, która ma różny przebieg, ponieważ jej cel, dynamika i role, w jakich występują uczestnicy, zależą od danego układu sytuacji, a rozmowa jest po prostu częścią określonego systemu. Pozwala ona na zajrzenie „do środka”, dzięki temu dostarcza bardzo cennej wiedzy - autentycznej, wynikającej z bycia ,tu i teraz". Jednak ta zaleta może być zarazem potraktowana jako ograniczenie, ponieważ badacz ma wgląd wyłącznie w to, co zaobserwował, w czym sam brał udział, reaguje tylko zgodnie z logiką sytuacji ${ }^{5}$. Innym rodzajem rozmowy, jaką udaje mi się czasami przeprowadzić, jest tzw. wywiad swobodny. Według moich przewodników w radzeniu sobie polega on na zadawaniu pytań in situ, kiedy wydarzenia biegną swoim torem. Pytania tego typu są częścią życia, ale mimo ich charakteru, który nie jest sprowokowany specjalnym zachowaniem i nastawieniem, informacje uzyskane na ich podstawie mogą być wykorzystane przez badacza naturalistycznego do celów poznawczych. Ów sposób rozmawiania ma pozór „zwykłej rozmowy" i jest głównym elementem obserwacji uczestniczącej (L o fl a n d i in. 2009: 132). W tej sytuacji można komentować nie pytając wprost i wnioskować na podstawie reakcji na komentarz. Dodałabym, że komentarz może być nie tylko złożony ze słów, ale także bezsłowny - bezgłośny, cielesny ${ }^{6}$.

Komentując jeden z tekstów Joanny Tokarskiej-Bakir, Marcin Brocki zauważył, że pojawiające się w nim słowo ,słuchanie” jest metaforą obserwacji (Brocki 2008: 140; patrz Tokarska-Bakir 1995: 13-22). W dużej mierze sama traktuję podobnie wsłuchiwanie się w fonikę schroniska (wypełnioną krzykiem lub ciszą) i noclegowni (gdzie panuje raczej szmer, choć zdarza się

${ }^{5}$ Lofland i Snow podają jeszcze jeden rodzaj rozmowy: wywiad intensywny, który może dotyczyć działania, które miało miejsce poza bezpośrednim kontekstem wywiadu. Wywiad to, według nich, ,przedstawienie skierowane do określonej publiczności” (L o fl a n d i in. 2009: 132), odpowiedzi są tak formułowane, by objaśnić badaczowi znaczenia przypisywane działaniom, które mają miejsce w danym układzie. Wywiad daje dostęp do wielu perspektyw, a badacz buduje rozumienie za pośrednictwem badanych.

${ }^{6}$ Między mną a kobietami oraz nimi nawzajem bardzo rzadko przydarza się interakcja fizyczna: nie podajemy sobie rąk na powitanie i pożegnanie; wyjątkowo dotykałyśmy się w inny sposób - np. z niektórymi spontanicznie uściskałyśmy się lub złapałyśmy za dłonie. Przydarzało się to tylko w momencie, kiedy gratulowałam przydziału mieszkania bądź jako wsparcie - w mniej pozytywnych chwilach. 
i krzyk, kiedy któraś z kobiet zaczyna się awanturować, jest nastawiona agresywnie). Ogranicza to moje działania (nie tylko antropologiczne, ale i pozaantropologiczne) w posługiwaniu się „naturalnym” narzędziem, za które uważa się wywiad, czyli rozmowę. Obserwacja implikuje przyglądanie się i zajęcie miejsca z boku (zgodnie z wyobrażeniem, że widać dopiero z pewnej odległości), polega na względnym odłączeniu się, oddaniu pola, wycofaniu się, nawet na zgodzie, aby być odsuniętym i niedopuszczonym. W obserwacji zawarte jest także słuchanie i nasłuchiwanie. Obserwacja wiąże się z biernością badacza. Według mnie jednak patrzenie i słuchanie wcale nie dystansuje badacza bardziej niż mówienie. Mówiąc, dokonujemy parafraz i translacji, zatem również się dystansujemy: cudze słowa i objaśnienia przekładamy na kategorie znane nam, w tym na terminy i wiązki objaśniające, jakie istnieją np. w antropologii. Wspólnota dyskursu, jaka powstaje między badaczem a rozmówcami, ma charakter wybitnie efemeryczny, doraźny i jednak celowy, gdzie liczy się przede wszystkim motywacja badacza (to on stawia kropkę wieńczącą całość pracy - tekst po badaniach; C 1 iff or d 2000). Podczas słuchania i patrzenia, traktowanych niejako automatycznie jako symbole dystansu, nie unikamy jednak ,zaangażowania” w sensie Goffmanowskim (G o f fman 2008: 39-196). Patrzenie i słuchanie również wymaga zajęcia miejsca i przyjęcia postawy. Jest to ustanowienie komunikacji i wejście w specyficzną relację dialogiczną - czego ostatnio doświadczam najczęściej - niewerbalną.

Mimo braku słów i bezpośrednich enuncjacji, które tak rzadko toczą się zarówno między mną a kobietami, jak i między nimi samymi, z pewnością „,W otaczającym mnie świecie rysuje się inne centrum, z którego, podobnie jak z mej własnej perspektywy, postrzegany jest świat [...]” (Mi c hali k 2010: 214).

\section{BIBLIOGRAFIA}

B a b i o r Sharman L. (2011), Participant and Observer: Reflection on Fieldwork in a Women's Shelter in Tokyo, Japan, [w:] Anthropology at the Front Lines of Gender-based Violence, J. R. Wies, H. J. Haldane (eds.), Vanderbilt University Press, Nashville, Tennessee, s. 29-50.

B r o c k i Marcin (2008), Antropologia. Literatura - dialog - przekład, Wydawnictwo KEiAK Uniwersytetu Wrocławskiego, Wrocław.

B u 1 i ń s k i Tarzycjusz, K a i r s k i Mariusz (red.) (2011), Teren w antropologii. Praktyka badawcza we wspótczesnej antropologii kulturowej, Wydawnictwo Naukowe UAM, Poznań.

B u t 1 e r Judith (2010), Walczace stowa, Wydawnictwo Krytyki Politycznej, Warszawa.

C h r i st i a n s Clifford G. (2009), Etyka i polityka w badaniach jakościowych, [w:] Metody badań jakościowych, t. 1, N. K. Denzin, Y. S. Lincoln (red.), Wydawnictwo Naukowe PWN, Warszawa, s. 207-244.

C 1 i f f o r d James (2000), O autorytecie etnograficznym, [w:] James C 1 iff o r d, Klopoty z kultura. Dwudziestowieczna etnografia, literatura i sztuka, Wydawnictwo KR, Warszawa, s. 105129.

C 1 i f f o r d James (2004), Praktyki przestrzenne: badania terenowe, podróże i praktyki dyscyplinujace w antropologii, [w:] Badanie kultury. Elementy teorii antropologicznej. Kontynuacje, E. Nowicka, M. Kempny (red.), Wydawnictwo Naukowe PWN, Warszawa, s. 139-179. 
D e c l e r c k Partick (2004), Rozbitkowie. Rzecz paryskich kloszardach, Wydawnictwo Muza, Warszawa.

F a ry n o Jerzy (1999), Skąd wiesz kiedy milczę?, [w:] Semantyka milczenia. Zbiór studiów, K. Handke (red.), Instytut Slawistyki PAN, Warszawa, cz. 1, s. 33-46.

G d u 1 a Maciej (2010), Wokót pojęcia wykluczenia w naukach społecznych, [w:] Jednostka zakorzeniona? Wykorzeniona?, A. Lompart (red.), Instytut Socjologii UW, Warszawa, s. 78-89.

G e e rt z Clifford (2005), Opis gęsty: w poszukiwaniu interpretatywnej teorii kultury, [w:] Clifford G e e r tz, Interpretacja kultur, Wydawnictwo Uniwersytetu Jagiellońskiego, Kraków, s. $17-48$.

G i r o la Claudia M. (1996), Rencontrer des personnes sans abri. Une anthropologie réflexive, „Politix”, no 34, s. 87-98.

G of f m a n Erving (2008), Zachowanie w miejscach publicznych. O spolecznej organizacji zgromadzeń, Wydawnictwo Naukowe PWN, Warszawa.

H a n d k e Kwiryna (1999a), Między mowa a milczeniem, [w:] Semantyka milczenia. Zbiór studiów, K. Handke (red.), Slawistyczny Ośrodek Wydawniczy przy Instytucie Slawistyki PAN, Warszawa, cz. 1, s. 9-16.

H a n d k e Ryszard (1999b), Milczenie w perspektywie oczekiwań, [w:] Semantyka milczenia. Zbiór studiów, K. Handke (red.), Slawistyczny Ośrodek Wydawniczy przy Instytucie Slawistyki PAN, Warszawa, cz. 1, s. 47-58.

J a d a c k i Jacek Juliusz (1999), O pojęciu milczenia, [w:] Semantyka milczenia. Zbiór studiów, K. Handke (red.), Instytut Slawistyki PAN, Warszawa, cz. 1, s. 17-32.

K a n i o w s k Katarzyna (2010), Skąd się biora etyczne problemy badań antropologicznych?, [w:] K. K a n i o w s k a, N. M o d n i c k a (red.), Etyczne problemy badań antropologicznych, ser. „,Łódzkie Studia Etnograficzne”, vol. 49, Polskie Towarzystwo Ludoznawcze, WrocławŁódź, s. 7-16.

K a u f m a n n Jean-Claude (2010), Wywiad rozumiejacy, Oficyna Naukowa, Warszawa.

K i j e w s k a Anna, K u ź m a Inga (2009), Święto Kurban Bajram w Bułgarii. O „etnicznych” odmianach świętowania - na wybranym przykładzie z terenu. Refleksje etnologiczne, „Etnografia Polska", t. 53, z. 1-2, s. 61-90.

K o ł t a n Jacek (2011), Wola władzy. Granice dialogu w doświadczeniu indywidualnym $i$ w ideologii wspólnoty, [w:] Dialog. Idea i doświadczenie, S. Kuszyńska, K. Bembennek, I. Krupecka (red.), Wydawnictwo Uniwersytetu Gdańskiego, Gdańsk, s. 109-117.

K o ś c i a ń s k a Agnieszka (2009), Potęga ciszy. Konwersja a rekonstrukcja porzadku płci na przykładzie nowego ruchu religijnego Brahma Kumaris, Wydawnictwa Uniwersytetu Warszawskiego, Warszawa.

K w a śn i e w sk i Jerzy (2010), Wplyw norm prawnych na procesy wykluczenia spolecznego, [w:] Prawo i wykluczenie. Studium empiryczne, A. Turska (red.), Wydawnictwo C.H. Beck, Warszawa, s. 189-202.

L i n c o 1 n Yvonna S. (2009), Komisje etyczne i konserwatyzm metodologiczny. Wyzwanie dla i ze strony paradygmatu fenomenologicznego, [w:] Metody badań jakościowych, t. 1, N. K. Denzin, Y. S. Lincoln (red.), Wydawnictwo Naukowe PWN, Warszawa, s. 255-268.

L o fl a n d John, S n o w Dawid A., A n d e r s o n Leon, L of 1 and Lyn H. (2009), Analiza uktadów społecznych. Przewodnik metodologiczny po badaniach jakościowych, Wydawnictwo Naukowe SCHOLAR, Warszawa.

Maryniak Agnieszka (1999), Milczace dzieci, [w:] Semantyka milczenia. Zbiór studiów, K. Handke (red.), Instytut Slawistyki PAN, Warszawa, cz. 1, s. 227-236.

M i c h a 1 i k Joanna (2010), Filozofia i głos, NOMOS, Kraków.

O l e a r c zy k Teresa (2010), Pedagogia ciszy, WAM, Kraków. 
R a k o w s k i Tomasz (2002), Antropolog jako wizytator nędzy. Rozważania o kulturze niemocy, „Kultura i Społeczeństwo”, vol. 46, nr 4, s. 67-79.

R a k o w s k i Tomasz (2009), Łowcy, zbieracze, praktycy niemocy: etnografia człowieka zdegradowanego, Wydawnictwo słowo/obraz terytoria, Gdańsk.

S e g a u d Marion (2007), Anthropologie de l'espace. Habiter, fonder, distribuer, transformer, Armand Colin, Paryż.

$\mathrm{S}$ z a r f e n b e r g Ryszard [b.d.w.], Marginalizacja i wykluczenie społeczne-panorama językowo-teoretyczna, http://rszarf.ips.uw.edu.pl/pdf/miws_panorama.pdf, 21.09.2011.

Ta r k o w s k a Elżbieta, W a r z y w o d a-K r u s z y ń s k a Wielisława, W ó d z Kazimiera (2003), Biedni o sobie i swoim życiu, Wydawnictwo Naukowe „Śląsk”, Katowice.

To k a r s k a-B a k i r Joanna (1995), Dalsze losy syna marnotrawnego. Projekt etnografii nieprzezroczystej, „Konteksty. Polska Sztuka Ludowa”, nr 1, s. 13-22.

Wa r z y w o d a-K r u s z y ń s k a Wielisława (2001), Żyć i pracować w enklawach biedy, Przedsiębiorstwo Specjalistyczne Absolwent, Łódź.

W ę g 1 a r z Stanisław (2010), Antropologia hermeneutyczna wobec tradycyjnych tekstów kulturowych, Wydawnictwo Uniwersytetu Śląskiego, Katowice.

W i e r c i ń s k i Hubert (2008), Historia czerwonych buteleczek, „(op.cit.,)”, vol. 41, nr 4, s. 50-54.

Wró b l e w s k i Filip, S o c h a c k i Łukasz, S t e b li k Jakub (red.) (2010), Antropologia zaangażowana (?), ser. „Prace Etnograficzne”, z. 38, Wydawnictwo Uniwersytetu Jagiellońskiego, Kraków.

\section{Inga B. Kuźma}

\section{INTRODUCTION TO ANTHROPOLOGICAL RESEARCH ON HOMELESS WOMEN. COMMUNICATION PROBLEMS WITH SUBJECTS}

The text introduces the multi-staged and lasting over a number of years research conducted by its author. The research takes place among homeless women from the shelters and sleeping homes in the city of Łódź. The author discusses here the problem of conducting such research, with the homeless women belonging to the type of subjects known as muted group. Since she gets involved and engaged in these women's life (at a certain stage she becomes a voluntary helper at one of the centers), her two-levelled presence among them will be a characteristic feature of her study. She cannot separate one of her functions from the other: the jobs of an anthropologist and of a charity employee are interwoven with each other. She highlights that the muted group phenomenon is not only a consequence of their own past experience, but also of the type of environment, with its rules and regulations, created in places like these. The author analyses how their silence and non-verbal expression symbolize their defiance, and become their own strategy of life and means of self-expression. At the same time, she suggests that the research practices need to be verified and adapted to the conditions of the environment.

Keywords: homeless women, muted group, homeless shelter, copying, silence, non-verbal expression, cry. 